\title{
KUALITAS FISIK DAN SENSORIS PRODUK SUSU PASTEURISASI PADA SUHU DAN WAKTU TRANSPORTASI DALAM DISTRIBUSI PEMASARAN
}

\author{
Physical Quality and Sensory of Pasteurized Milk Products in Temperature and \\ Transportation Time in Marketing Distribution \\ Mulia Winirsya Apriliyani ${ }^{1)}$, M W Apriliyanti ${ }^{2)}$ \\ 1) Teknologi Hasil Ternak, Fakultas Peternakan Universitas Brawijaya, Jl. Veteran. Malang, Jawa Timur. Indonesia. 65145 \\ 2) Teknologi Pertanian, Politeknik Negeri Jember, Jl. Mastrip Kotak Pos 164, Sumbersari, Jawa Timur 68121 \\ muliaapriliyani@ub.ac.id
}

Diterima 27 Februari 2018; diterima pasca revisi 23 Maret 2018

Layak diterbitkan 28 Maret 2018

\begin{abstract}
The aim of this research was to determine the influence of the long time transportation for 72 , 108 , and 129 hours at a temperature $-15^{\circ} \mathrm{C}, 5^{\circ} \mathrm{C}$, and $15^{\circ} \mathrm{C}$. The materials used for this research was pasteurized milk packaging bottle $250 \mathrm{ml}$ made in by UKM in Malang City. The study is conducted through simulate transportation with 9 treatment and 3 replications. The treatment were 72, 108, and $129 \mathrm{~h}$ with temperature $15^{\circ} \mathrm{C}, 5^{\circ} \mathrm{C}$, and $-15^{\circ} \mathrm{C}$. The variable observed were the $\mathrm{pH}$, syneresis and sensory (taste test, scent, texture and the bottle condition). Data analyzed by the descriptive analytic research. The $p H$ values ranging from 4.6-6.7 and sineresis 55.03-93.88 \%. Characteristic of pasteurized milk in the sensory (taste, aroma, texture and the bottle condition) tend to good condition, normal and bulging at a temperature of packaging $5^{\circ} \mathrm{C}$. Based on the normal milk of pH still in its approach is still normal sensory and properties, and marketing pasteurized milk can be done by long hours for the purpose of transportation 72-108 (location distribution Jember, Pekalongan, Yogyakarta, Sumenep, Denpasar, Mataram, dan Balikpapan) at a temperature of packaging $5^{\circ} \mathrm{C}$.
\end{abstract}

Keywords : Pasteurized milk; temperature; transportation; marketing distribution

\begin{abstract}
ABSTRAK
Penelitian ini bertujuan untuk menentukan pengaruh lama transportasi selama 72, 108, dan 129 jam pada suhu pengemasan $-15^{\circ} \mathrm{C}, 5^{\circ} \mathrm{C}$, dan $15^{\circ} \mathrm{C}$. Materi yang digunakan adalah susu pasteurisasi kemasan botol $250 \mathrm{ml}$ salah satu produksi UKM di Kota Malang. Penelitian ini dilakukan melalui mensimulasi transportasi dengan 9 perlakuan dan 3 ulangan selama 72, 108, dan 129 jam masing-masing pada suhu $15^{\circ} \mathrm{C}$, $5^{\circ} \mathrm{C}$, dan $15^{\circ} \mathrm{C}$. Variabel yang diamati uji $\mathrm{pH}$, uji sineresis dan uji sensoris (rasa, aroma, tekstur dan kondisi botol). Data hasil penelitian dianalisis dengan uji deskriptif analitik. Hasil nilai pH berkisar antara 4,6-6,7 dan sineresis 55,03-93,88\%. Karakteristik susu pasteurisasi secara sensoris (rasa, aroma, tekstur dan kondisi botol) cenderung enak, normal dan tidak menggembung pada suhu pengemasan $5^{\circ} \mathrm{C}$. Berdasarkan nilai pH yang masih mendekati susu normal dan sifat sensoris masih normal, maka pemasaran susu pasteurisasi dapat dilakukan distribusi dengan lama transportasi 72-108 jam (untuk tujuan distribusi Jember, Pekalongan, Yogyakarta, Sumenep, Denpasar, Mataram, dan Balikpapan) dengan suhu pengemasan $5^{\circ}$ C. Penelitian ini memberikan sumbangan yang sangat penting dalam memberikan informasi dalam distribusi produk susu fermentasi dalam mengontrol suhu dan waktu transportasi.
\end{abstract}

Kata Kunci: Susu pasteurisasi; suhu; transportasi; distribusi pemasaran 


\section{PENDAHULUAN}

Susu pasteurisasi merupakan cara mengawetkan susu melalui pemanasan pada suhu $72^{\circ} \mathrm{C}$, hasil produk susu pasteurisasi masih mempunyai rasa dan bentuk seperti susu segar dengan masa simpan 8 sampai 10 hari.Pemanasan pada suhu dibawah titik didih ini menyebabkan susu pasteurisasi masih belum bebas dari sejumlah mikroorganisme (Niamsuwan, et al., 2014). Adanya mikroorganisme dalam susu pasteurisasi mengakibatkan produk mempunyai daya simpan yang terbatas dan harus disimpan pada suhu dibawah $100^{\circ} \mathrm{C}$. Tujuan pasteurisasi susu adalah untuk membunuh bakteri patogen dan non patogen (pembusuk dan perusak), sekaligus untuk meningkatkan mutu susu. Menurut Sunarlim dan Widaningrum (2005), pasteurisasi dilakukan untuk membunuh bakteri patogen sebagian besar mikroba tetapi spora bakteri dan berbagai bakteri tertentu belum mati, sehingga daya simpannya relatif lebih singkat. Keadaan susu secara sensoris masih normal pada semua waktu distribusi 72,108 , dan 129 jam pada suhu $5^{\circ} \mathrm{C}$. Kondisi botol yang mengembung pada $\mathrm{pH} 5$ dapat diperkirakan terjadi proses pembentukan toksik Staphylococcus aureus karena pada $\mathrm{pH}$ antara 5,0 sampai 6,5 protein yang cukup dapat digunakan Staphylocccus aureus untuk memproduksi enzim seperti protease, lipase dan koagulase. Perbedaan nilai $\mathrm{pH}$ karena tingkat kebanyakan mikroba tumbuh baik pada pH sekitar netral, dan $\mathrm{pH}$ 4,6 - 7,0 merupakan kondisi optimum untuk pertumbuhan bakteri.

Distribusi pemasaran produk susu pasteurisasi tanpa pengawet maupun bahan tambahan pangan memang akan lebih sulit karena akan terjadinya penurunan kualitas produk. Distribusi yang dilakukan misalnya melalui transportasi darat, laut dan udara perlu

*Corresponding author:

Mulia Winirsya Apriliyani

Email : muliaapriliyani@ub.ac.id

Teknologi Hasil Ternak, Fakultas Peternakan

Universitas Brawijaya, Jl. Veteran. Malang, Jawa

Timur. Indonesia. 65145 didukung oleh suhu pengemasan produk. Orientasi pengembangkan Usaha Kecil Menengah (UKM) bagi masyarakat menuntut para pelaku usaha sangat ketat dalam persaingan bisnis sehingga membutuhkan keberanian mengambil resiko akses pasar. UKM dapat merespon keinginan pelanggan yang berada diluar pulau Jawa melalui manajemen pengemasan sehingga aman saat melewati jalur distribus dengan resiko lamanya transportasi. Distribusi merupakan proses pengiriman produk melalui transportasi darat, air, maupun udara yang memerlukan waktu. Seiring dengan lamanya transportasi tentu akan mempengaruhi kualitas fisik maupun sensoris produk. Pengaruh lamanya transportasi berpengaruh terhadap penurunan kualitas $\mathrm{pH}$ dan sineresis.

Waktu transportasi berpengaruh pada pengemasan, karena selama transportasi terjadi perubahan karena kondisi lingkungan. Menurut Restuccia et al. (2010), keaktifan pengemasan adalah untuk meningkatkan pengawetan makanan dalam memperpanjang umur simpan melibatkan penerapan berbagai strategi seperti kontrol suhu, penghilangan oksigen, kontrol kelembaban, penambahan bahan kimia seperti garam, gula, karbondioksida atau asam alami atau kombinasi ini dengan kemasan yang efektif. Perkembangan saat ini dalam kemasan aktif telah menyebabkan kemajuan di banyak bidang termasuk oksidasi tertunda dalam makanan otot, tingkat respirasi yang dikendalikan dalam produk hortikultura, pertumbuhan mikroba dan migrasi kelembaban dalam produk kering (Brody et al. 2008).

Penelitian ini didasari beberapa permasalahan sering dialami oleh beberapa UKM susu dan yogurt yang ada di Kota Malang yaitu bagaimana mempertahankan kesegaran dari susu pasteurisasi selama mengalami pengiriman antar pulau. Banyak

\footnotetext{
How to cite:

Apriliyani, M.W., \& Apriliyanti, M.W. (2018).

Kualitas Fisik dan Sensoris Produk Susu

Pasteurisasi pada Suhu dan Waktu Transportasi dalam Distribusi Pemasaran. Jurnal Ilmu dan Teknologi Hasil Ternak, 13 (1), 46-53
} 
tawaran bagi UKM ini untuk memperluas wilayah pemasaran ke Jember, Pekalongan, Yogyakarta, Sumenep, Denpasar, Mataram, Balikpapan, dan Pekanbaru. Sebagian besar produk UKM merupakan produk dengan penerapan teknologi yang masih sederhana serta tidak menggunakan bahan pengawet maupun bahan penstabil. Oleh karena itu, bagaimana konsumen atau pelanggan merasa puas dengan produk sampai pada kota tujuan dengan aman dan segar. Penelitian Kristanti (2017) berkaitan dengan daya simpan susu pasteurisasi ditinjau dari kualitas mikroba termodurik dan kualitas kimia, dengan daya simpan susu pasteurisasi pada suhu pemanasan yang lebih tinggi tidak terjadi perubahan secara signifikan pada kandungan gizi susu serta mempunyai masa simpan yang lebih lama.Menurut Gandy et al. (2008), daya simpan susu pasteurisasi yang disimpan pada suhu $7^{\circ} \mathrm{C} \pm 10^{\circ} \mathrm{C}$ berkisar antara 10 sampai dengan 21 hari. Faktor-faktor yang mempengaruhi kualitas susu pasteurisasi adalah kualitas bahan baku, jumlah bakteri awal, kondisi proses pengolahan, bahan pengemas, kontaminasi setelah proses pasteurisasi dan kondisi penyimpanan. Setiap kenaikan suhu penyimpanan $30^{\circ} \mathrm{C}$, maka daya simpan susu pasteurisasi akan berkurang menjadi setengahnya. Selain daya simpan, sebenarnya banyak pertanyaan di masyarakat tentang bagaimana kondisi susu pasteurisasi yang mengalami distribusi dengan jauhnya jarak dan lamanya waktu pemasaran terhadap kualitas produk.

Pengujian kualitas berupa uji $\mathrm{pH}$ dan sineresis sedangkan uji sensoris meliputi rasa, aroma, tekstur, dan keadaan botol. Menurut Spilimbergo (2011) bahwa penemuan ilmu modern tentang proses pasteurisasi dengan suhu rendah merupakan teknik inaktivasi pada suhu non termal bertujuan untuk mempertahankan kesegaran produk, memperpanjang masa simpan, dan sifat sensoris kualitas tinggi. Pada produk yang mengalami perlakuan mengalami perbedaan nilai $\mathrm{pH}$ sebelum dan sesudah, berdasarkan pengaruh peningkatan dissolusi kinetik dari fase gas masuk dalam fase cair. Suhu pengemasan dan lama transportasi secara langsung mempengaruhi energi kinetik molekul dalam cairan susu. Pengaruh suhu terhadap cairan berkaitan dengan teori kinetik molekuler. Menurut Walstra, et al (2005) kenaikan suhu susu menyebabkan kenaikan kecepatan rata-rata molekulnya seiring suhu susu meningkat, molekul bergerak lebih cepat sehingga meningkatkan energi kinetik cairan.

\section{MATERI DAN METODE}

Materi yang digunakan adalah susu pasteurisasi kemasan botol $250 \mathrm{ml}$ salah satu produksi UKM di Kota Malang. Bahan lain yang digunakan untuk analissis $\mathrm{pH}$ adalah larutan buffer 4 , buffer 7 , dan aquades, Alat yang digunakan untuk persiapan adalah termometer, kulkas, freezer, $\mathrm{pH}$ meter, ice gel, sentrifuge, tabung reaksi, gelas ukur $50 \mathrm{ml}$, dan box pengemas styrofoam ukuran sedang (ukuran luar 20 x 24 x $28 \mathrm{~cm}$, dalam 14 x 19 x $24 \mathrm{~cm})$.

Penelitian ini dilakukan dengan 9 perlakuan dan 3 ulangan. Perlakuan yang dicobakan yaitu :

$\mathrm{P} 1=$ Susu pasteurisasi dengan suhu pengemasan $-15^{\circ} \mathrm{C}$ selama 72 jam

$\mathrm{P} 2=$ Susu pasteurisasi dengan suhu pengemasan $5^{\circ} \mathrm{C}$ selama 72 jam

$\mathrm{P} 3=$ Susu pasteurisasi dengan suhu pengemasan $15^{\circ} \mathrm{C}$ dengan penambahan ice gel selama 72 jam

$\mathrm{P} 4=$ Susu pasteurisasi dengan suhu pengemasan $-15^{\circ} \mathrm{C}$ selama 108 jam

$\mathrm{P} 5=$ Susu pasteurisasi dengan suhu pengemasan $5^{\circ} \mathrm{C}$ selama 108 jam

$\mathrm{P} 6=$ Susu pasteurisasi dengan suhu pengemasan $15^{\circ} \mathrm{C}$ dengan penambahan ice gel selama 108 jam

$\mathrm{P7}=$ Susu pasteurisasi dengan suhu pengemasan $-15^{\circ} \mathrm{C}$ selama 129 jam

$\mathrm{P} 8=$ Susu pasteurisasi dengan suhu pengemasan $5^{\circ} \mathrm{C}$ selama 129 jam

$\mathrm{P} 9=$ Susu pasteurisasi dengan suhu pengemasan $15^{\circ} \mathrm{C}$ dengan penambahan ice gel selama 129 jam 
Langkah-langkah penelitian ini, dengan uraian sebagai berikut:

1. Persiapan produk susu pasteurisasi kemasan botol $250 \mathrm{ml}$ dengan varian rasa.

2. Pengawetan produk pada suhu pendinginan dan pembekuan

a. Dilakukan pendinginan pada suhu $-15^{\circ} \mathrm{C}$

b. Dilakukan pembekuan pada suhu $5^{\circ} \mathrm{C}$

c. Dilakukan pembekuan suhu $15^{\circ} \mathrm{C}$ penambahan ice gel

3. Perlakuan simulasi pengiriman antar pulau produk susu pasteurisasi dilakukan denganmengkondisikan keadaan pengiriman (transportasi) berdasarkan jarak dan lama perjalanan, getaran, dan goncangan dapat dilihat pada Tabel 1 .

Tabel 1. Daftar Simulasi Estimasi Waktu Pengiriman berdasarkan Tujuan Distribusi

\begin{tabular}{cc}
\hline Tujuan distribusi & Estimasi \\
& Lama Transportasi (jam) \\
\hline Malang - Jember & $48-72$ \\
Malang - Pekalongan & $48-72$ \\
Malang - Yogyakarta & $48-72$ \\
Malang - Sumenep & $48-72$ \\
Malang - Denpasar & $48-72$ \\
Malang - Mataram & $72-108$ \\
Malang - Balikpapan & $72-108$ \\
Malang-Pekanbaru & 129 \\
\hline
\end{tabular}

Variabel Penelitian

Variabel yang diamati dalam penelitian ini adalah:

Uji pH : Penentuan nilai pH dilakukan dengan menggunakan $\mathrm{pH}$ meter sesuai dengan AOAC (2005), pengujian sineresis dilakukan dengan $\mathrm{pH}$ meter diatur dengan larutan buffer sampai nilai 7 , kemudian mencelupkan $\mathrm{pH}$ meter ke dalam sampel sehingga terbaca nilai pHnya.

Uji Sineresis :suatu proses pengkerutan atau kontraksi gel protein akibat adanya peningkatan interaksi protein-protein dan menurunnya interaksi protein-air, sehingga memacu pembentukan curd bersamaan dengan terjadinya pemisahan whey (Renault et al., 1997; Fox, 1987; Hui, 1993). Pengujian sineresis dilakukan dengan menggunakan alat sentriguge pada kecepatan $500 \mathrm{rpm}$ selama 510 menit.Persentase (\%) sineresis yaitu perbandingan volume supernatant dan sampel (ml) dikali 100\%.

Uji sensoris: uji untuk melihat keadaan rasa, aroma, tekstur dan kondisi botol. Karakteristik rasasusu pasteurisasi yaitu rasa enak, aroma khas susu, tekstur normal (encer, halus, penampakan susu menyatu dan tidak ada pemisahan/ konsistensi homogen dalam cairannya, kondisi lemak susu naik di permukaan botol), dan kondisi botol tidak menggembung. Jika susu pasteurisasi sudah tidak memenuhi kriteria tersebut, maka dikatakan tidak normal. Pengujian sensoris dalam penelitian ini dilakukan 5 orang panelis terlatih dari pihak UKM terkait yaitu pemilik UKM 1 orang, distributor 2 orang, pelanggan tetap UKM 2 orang. Uji sensoris dengan skala 1-5 (mulai dari tidak suka-suka, tidak enakenak).

\section{Analisis Data}

Uji deskriptif, yaitu penelitian untuk mendapatkan gambaran yang utuh tentang karakteristik suatu produk. Oleh sebab itu, pada uji ini banyak sifat yang sensorik yang dinilai dan dianalisis secara keseluruhan(Surakhmad 2004).Sifat-sifat sensorik yang dipilih adalah terutama yang paling relevan terhadap mutu atau yang paling peka terhadap perubahan mutu yaitu rasa, aroma, tekstur, dan kondisi Data hasil penelitian dianalisis dengan uji deskriptif analitik yaitu metode penelitian yang memusatkan diri pada pemecahan masalah - 
masalah yang aktual dan selanjutnya data yang telah dikumpulkan mula-mula disusun, dijelaskan kemudian dianalisis.

\section{HASIL DAN PEMBAHASAN}

\section{Hubungan Nilai pH dan Uji SensorisSusu Pasteurisasi selama Transportasi}

Produk susu pasteurisasi yang berkualitas baik dapat ditinjau dari keamanan bahan baku utama susu segar. Selain bahan baku, pengolahan produk, dan proses distribusi menentukan hasil akhir karakteristik. Lamanya waktu distribusi mempengaruhi kualitas produk. Berdasarkan data dalam Tabel 2 nilai rata-rata $\mathrm{pH}$ susu pasteurisasi 4,7-6,7.

Tabel 2. Nilai pH dan Sineresis Produk Yogurt Botol setelah Mengalami Distribusi

\begin{tabular}{ccccccc}
\hline \multicolumn{1}{c}{ Perlakuan } & \multicolumn{5}{c}{ Nilai $\mathrm{pH}$} \\
\hline P1 & Lama Transportasi (Jam) & Suhu $\left({ }^{\circ} \mathrm{C}\right)$ & 1 & 2 & 3 & Rerata \\
P2 & \multirow{2}{*}{72} & -15 & 6,1 & 6,0 & 6,0 & 6,0 \\
P3 & & 5 & 6,7 & 6,7 & 6,8 & 6,7 \\
P4 & & 15 & 5,0 & 5,4 & 5,4 & 5,3 \\
P5 & \multirow{2}{*}{108} & -15 & 4,7 & 4,7 & 4,8 & 4,7 \\
P6 & & 5 & 6,3 & 6,3 & 6,4 & 6,3 \\
P7 & & 15 & 5,1 & 5,0 & 5,0 & 5,0 \\
P8 & \multirow{2}{*}{129} & -15 & 5,2 & 4,8 & 4,8 & 4,9 \\
P9 & & 5 & 5,4 & 5,4 & 5,4 & 5,4 \\
\end{tabular}

Nilai $\mathrm{pH}$ susupasteurisasi mendekati $\mathrm{pH}$ normal 6,6-6,8 (Murti, 2010). Banyak reaksi yang terjadi baik secara enzimatis dan mikrobiologis yang akan mempengaruhi ketahanan produk.Pada Tabel 3pada lama transportasi 72 jam dengan suhu $5^{\circ} \mathrm{C}(\mathrm{P} 2)$ nilai $\mathrm{pH}$ 6,7-6,8 ini menunjukkan sesuai dengan $\mathrm{pH}$ susu pasteurisasi secara normal, hal ini didukung dengan kondisi sensoris yang masih normal berbeda dengan lama transportasi 108 jam dengan suhu $5^{\circ} \mathrm{C}(\mathrm{P} 5)$ dan 129 jam dengan suhu $5^{\circ} \mathrm{C}(\mathrm{P} 8)$ nilai $\mathrm{pH}$ menurun menjadi 5,46,4 ini menunjukkan tidak sesuai dengan $\mathrm{pH}$ susu pasteurisasi secara normal, tetapi untuk kondisi sensoris yang masih normal. Kondisi sensoris susu pasteurisasi yang masih normal dari segi rasa, tekstur dan botol karena gel yang terbentuk pada $\mathrm{pH}$ yang lebih tinggi pada kondisi nilai $\mathrm{pH}$ 5,4-6,8 terjadi interaksi protein dengan air yang lebih banyak sehingga tekstur masih cenderung normal tidak mengalami pemisahan. Rasa dan aroma susu pasteurisasi berasal dari senyawa volatil yang terakumulasi di dalam kemasan primer sebagai akibat dari degradasi makanan seperti aldehid, amina dan sulfida (Day, 2008). Berbeda halnya dengan suhu kemas dan suhu produk $-15^{\circ} \mathrm{C}$ dengan lama transportasi 72, 108, dan 129 jam, kondisi kualitas ketahanan produk dari segi nilai $\mathrm{pH}$ dan sensoris menurun, karena karakteristik susu.

Tabel 3. Penerimaan Konsumen melalui Kondisi Sensoris

\begin{tabular}{|c|c|c|c|c|c|c|}
\hline & \multicolumn{2}{|l|}{ Perlakuan } & \multicolumn{4}{|c|}{ Mutu Sensoris } \\
\hline & $\begin{array}{c}\text { Lama Transportasi } \\
\text { (Jam) }\end{array}$ & $\begin{array}{c}\text { Suhu } \\
\left({ }^{\circ} \mathrm{C}\right)\end{array}$ & Rasa & Aroma & Tekstur & Kondisi Botol \\
\hline $\mathrm{P} 1$ & & -15 & Enak & Khas susu & Tidak normal & Normal \\
\hline $\mathrm{P} 2$ & 72 & 5 & Enak & Khas susu & Normal & Normal \\
\hline P3 & & 15 & Tidak enak & Bau Asam & Tidak normal & Menggembung \\
\hline $\mathrm{P} 4$ & & -15 & Tidak enak & Bau Asam & Masih normal & Menggembung \\
\hline P5 & 108 & 5 & Enak & Khas susu & Normal & Normal \\
\hline P6 & & 15 & Tidak Enak & Bau Asam & Normal & Menggembung \\
\hline P7 & & -15 & Tidak enak & Bau Asam & Tidak normal & Menggembung \\
\hline P8 & 129 & 5 & Enak & Khas susu & Masih normal & Normal \\
\hline P9 & & 15 & Tidak enak & Bau Asam & Tidak normal & Menggembung \\
\hline
\end{tabular}


Padalama transportasi 108 dan 129 jam dengan suhu $15^{\circ} \mathrm{C}$ semua produk yang mengalami penurunan yaitu 4,6-5,3 serta kondisi sensoris cenderung menunjukan ketidak normalan baik dari segi rasa, tekstur, dan kondisi botol. Hal ini menunjukkan bahwa terjadi penurunan $\mathrm{pH}$ susu dipengaruhi oleh adanya aktivitas mikrobiologis. Glukosa dan atau galaktosa akan dimanfaatkan bakteri asam laktat skemudian menghasilkan produk akhir asam laktat sehingga meningkatkan keasaman produk atau menurunkan nilai $\mathrm{pH}$. Penurunan nilai $\mathrm{pH}$ diikuti dengan kondisi ketidaknormalan rasasusu pasteurisasi dalam botol kemasan karena meningkatnya kemanisan susu pasteurisasi. Hal ini menunjukkan aktivitas mikrobia pencemar secara cepat pula.Secara fisik, penurunan nilai $\mathrm{pH}$ pada susu pasteurisasi selama distribusikarena menurunnya interaksiantara protein dengan air, seiring dengan penurunan nilai $\mathrm{pH}$ yang drastis 4,6-5,3 juga menurunnya kualitas sensoris yaitu rasa susu yang tidak enak, tekstur yang tidak normal, dan botol yang menggembung diperkirakan bahwa interaksi proteinada yang mengalami pengkerutan gel protein yang menyebabkan pembentukan curd dan terjadinya pemisahan whey. Kondisi botol penggembungan juga dipengaruhi bahan kemasan susu botol plastik. Menurut Ghenai (2012), kemasan berbahan polietilen berdensitas tinggi dan bahan polietilen berdensitas rendah digunakan untuk tutup botol. Polymer moulding adalah proses pembuatan yang digunakan untuk botol dan tutup botol plastik. Setelah pengemasan selanjutnya berada pada fase transportasi, dimana pengangkutan dari tempat produksi sampai ke pelanggan. Sehingga perlu diperhatikan efisiensi transportasi, dan jarak.

\section{Hubungan Nilai Sineresis dengan Nilai Sensoris Tekstur Susu Pasteurisasi selama Transportasi}

Sineresis adalah peristiwa keluarnya air dari dalam gel dimana gel mengkerut sehingga cenderung memeras air keluar dari dalam sel, akibatnya gel nampak lebih kecil dan padat.Berdasarkan Tabel 4, nilai sineresis tertinggi pada perlakuan lama transportasi 108 jam dengan suhu $15^{\circ} \mathrm{C}$ dengan penambahan ice gel (P7) sebesar 93,88\% dan terendah pada perlakuanlama transportasi 108 jam dengan suhu $-15^{\circ} \mathrm{C}$ (P6) sebesar 55,03\%. Angka sineresis yang tinggi menunjukkan gel tidak stabil secara fisik terhadap penyimpanan pada suhu $\pm 10^{\circ} \mathrm{C}$ (Kuncari, et al., 2014)

Tabel 4. Nilai Sineresis Susu Pasteurisasi selama Transportasi

\begin{tabular}{ccccccc}
\hline & Perlakuan & \multicolumn{5}{c}{ Nilai Sineresis (\%) } \\
\hline & $\begin{array}{c}\text { Lama Transportasi } \\
(\mathrm{Jam})\end{array}$ & $\begin{array}{c}\text { Suhu } \\
\left({ }^{\circ} \mathrm{C}\right)\end{array}$ & 1 & 2 & 3 & Rerata \\
\hline P1 & & 15 & 90,10 & 90,57 & 91,07 & 90,58 \\
P2 & 72 & 5 & 90,60 & 92,87 & 96,80 & 93,20 \\
P3 & & -15 & 74,9 & 74,56 & 74,14 & 74,53 \\
P4 & \multirow{2}{*}{108} & 15 & 81,43 & 77,10 & 78,41 & 78,98 \\
P5 & & 5 & 93,25 & 95,99 & 92,39 & 93,88 \\
P6 & \multirow{2}{*}{129} & -15 & 59,84 & 50,46 & 54,80 & 55,03 \\
P7 & & 15 & 94,44 & 94,02 & 92,44 & 93,63 \\
P8 & & 5 & 76,05 & 78,36 & 79,66 & 78,07 \\
P9 & & -15 & 77,85 & 79,44 & 78,59 & 78,63 \\
\hline
\end{tabular}

Stabilitas yang tinggi akan mengurangi terbentuknya whey dengan total solid yang tinggi maka tekstur pada produk fermentasi akan lebih baik (Kiani et al., 2008). Terjadinya pemisahan air dan padatan pada produk fermentasi disebabkan adanya gaya gravitasi selama produksi, tingkat keasaman yang tinggi, suhu inkubasi dan lamanya penyimpanan (Jaziri et al., 2009). Semakin tinggi suhu susu, semakin rendah viskositasnya karena 
peningkatan energi kinetik mengurangi kekuatan daya tarik antarmolekul. Faktor yang mempengaruhi sineresis pada produk fermentasi, antara lain adalah keasaman dan $\mathrm{pH}$, serta daya ikat air, sineresis juga dipengaruhi oleh kandungan protein bahan baku, terjadinya sineresis kemungkinan disebabkan oleh perubahan kelarutan kasein dan pengkerutan partikel kasein (Farinde et al., 2010).

Kestabilan mutu suatu produk ditentukan oleh banyaknya sifat produk yang menunjukkan kemampuannya dalam memuaskan kebutuhan yang diharapkan. Mutu menggambarkan keseluruhan gabungan karakteristik produk pada proses produksi, produk akhir hingga pemasaran. Berdasarkan Tabel 3 dan 4, bahwa hasil sineresis yang rendah akan mempengaruhi keadaan tekstur susu pasteurisasi dan kondisi botol yang menggelembung. Lama transportasi mengakibatkan energi kinetik berbanding lurus dengan suhu, cairan yang dipanaskan berlebih akan membentuk gas. Seiring suhu cairan turun, kecepatan molekulnya melambat. Kecepatan molekul yang melambat, akan mengurangi energi kinetik, sehingga meningkatkan daya tarik antarmolekul cairan. Daya tarik ini pada gilirannya membuat cairan lebih kental karena viskositas berbanding terbalik dengan suhu fluida. Oleh karena itu, jika cairan didinginkan secukupnya, kemungkinan akan mengkristal, berubah menjadi bentuk padatnya. Perubahan sineresis dan tekstur dari susu pasteurisasi berasal dari energi kinetik selama transportasai 72-129 jam. Menurut

$\underline{B i j i}$, et al (2015),suhu sebagai salah satu faktor lingkungan terpenting yang menentukan kinetika pembusukan fisik, kimiawi dan mikroba dalam produk makanan. Indikator suhu dan waktu dimaksudkan untuk memberikan informasi tentang apakah suhu ambang batas telah terlampaui dari waktu ke waktu dan untuk memperkirakan jumlah minimum waktu yang dihabiskan suatu produk selama distribusidan penyimpanan, sehingga dapat mengontrol suhu untuk produk dingin atau beku.

\section{KESIMPULAN}

Karakteristik susu pasteurisasi secara sensoris cenderung enak, normal dan tidak menggembung pada suhu pengemasan $5^{\circ} \mathrm{C}$. Nilai pH yang masih mendekati susu normal, pemasaran susu pasteurisasi dapat dilakukan dengan lama transportasi 72-108 jam (untuk tujuan distribusi Jember, Pekalongan, Yogyakarta, Sumenep, Denpasar, Mataram, dan Balikpapan). Penelitian ini memberikan sumbangan yang sangat penting dalam memberikan informasi dalam distribusi produk susu fermentasi dalam mengontrol suhu dan waktu transportasi.

\section{DAFTAR PUSTAKA}

AOAC. 2005. Official methode of analysis of the association analitical chemist. Washington DC: Inc.

Biji, K. B., Ravishankar, C. N., Mohan, C. O., \& Srinivasa Gopal, T. K. (2015). Smart packaging systems for food applications: a review. Journal of Food Science \& Technology, 52(10), 6125-6135. https://doi.org/10.1007/s13197-015-1766-7

Brody, A. L., Bugusu, B., Han, J. H., Sand, C. K., \& McHugh, T. H. (2008). Scientific status summary. Journal of Food Science, 73(8), R107-R116. https://doi.org/10.1111/j.17503841.2008.00933.x

Buckle, K. A., Purnomo, H., \& Adiono. N. D. Ilmu pangan Edisi Ke 2. Jakarta : Penerbit Universitas Indonesia, 1985.

Kerry, J., \& Butler, P. (2008). Smart packaging technologies for fast moving consumer goods. Chichester, UK: John Wiley \& Sons, Ltd. https://doi.org/10.1002/9780470753699 
Farinde E.O., Obatolu, V. A., Oyarekua, M. A., Adeniran, H. A., Ejoh, S. I. ., \& lanipekun, O. T. (2010). Physical \& microbial properties of fruit flavoured fermented cowmilk \& soy milk (yoghurt-like) under different temperature of storage. African Journal of Food Science \& Technology, 1(5), 120-127.

Fox, P. F. (2004). Cheese: chemistry, physics, \& microbiology. Elsevier.

Gandy, A. L., Schilling, M. W., Coggins, P. C., White, C. H., Yoon, Y., \& Kamadia, V. V. (2008). The effect of pasteurization temperature on consumer acceptability, sensory characteristics, volatile compound composition, \& shelf-life of fluid milk. Journal of Dairy Science, 91(5), 1769-1777. https://doi.org/10.3168/jds.2007-0833

Ghenai, C. (2012). Life cycle assessment of packaging materials for milk \& dairy products. Int. J. of Thermal \& Environmental Engineering , 4(2), 117-128.

Jaziri, I., Ben Slama, M., Mhadhbi, H., Urdaci, M. C., \& Hamdi, M. (2009). Effect of green \& black teas (Camellia sinensis L.) on the characteristic microflora of yogurt during fermentation \& refrigerated storage. Food Chemistry, 112(3), 614-620. https://doi.org/10.1016/J.Foodchem.2008.06. 017

Kiani, H., Mohammad Ali Mousavi, S., \& EmamDjomeh, Z. (2008). Rheological properties of iranian yoghurt drink, doogh. International Journal of Dairy Science, 3(2), 71-78. https://doi.org/10.3923/ijds.2008.71.78

Kristanti, N. D. (2017). Daya simpan susu pasteurisasi ditinjau dari kualitas mikroba termodurik \& kualitas kimia. Jurnal Ilmu \& Teknologi Hasil Ternak, 12(1), 1-7.

Kuncari, S. E., Iskandarsyah., \& Praptiwi. (2014). Evaluasi, uji stabilitas fisik \& sineresis sediaan gel yang mengandung minoksidil, apigenin \& perasan herba seledri (apium graveolens 1.) . Buletin Penelitian Kesehatan. Buletin Penelitian Kesehatan, 42(2), 213222.
Murti, T. W. (2010). Pasca panen \& industri susu. Fakultas Peternakan Universitas Gadjah Mada, Yogyakarta.

Niamsuwan, S., Kittisupakorn, P., \& Mujtaba, I. M. (2014). Control of milk pasteurization process using model predictive approach. Computers \& Chemical Engineering, 66, 211.

https://doi.org/10.1016/J.Compchemeng.201 4.01.018

Restuccia, D., Spizzirri, U. G., Parisi, O. I., Cirillo, G., Curcio, M., Iemma, F., \& Picci, N. (2010). New EU regulation aspects \& global market of active \& intelligent packaging for food industry applications. Food Control, 21(11), $1425-1435$ https://doi.org/10.1016/J.Foodcont.2010.04.0 28

Renault, C., Gastaldi, E., Lagaude, A., CUQ, J. L., \& Fuente, B. T. (1997). Mechanisms of syneresis in rennet curd without mechanical treatment. Journal of Food Science, 62(5), 907-910. https://doi.org/10.1111/j.13652621.1997.tb15004.x

Spilimbergo, S. (2011). Milk pasteurization at low temperature under $\mathrm{N}_{2} \mathrm{O}$ pressure. Journal of Food Engineering, 105(1), 193-195. https://doi.org/10.1016/J.JFOODENG.2011.0 $\underline{2.006}$

Sunarlim, R., \& Widaningrum. (2005). Cara pemanasan, suhu \& lama penyimpanan terhadap masa simpan susu kambing. Seminar Nasional Teknologi Peternakan \& Veteriner.

Surakhmad, W. (2004). Pengantar Penelitian Ilmiah: Dasar Metoda Teknik. Padang: Tarsito.

Walstra P et al. 2005. Dairy technology: principles of milk properties \& processes. CRC/Taylor $\&$ Francis. New York. 